\title{
TINGKAT KEPATUHAN MAHASISWA DALAM PENERAPAN PROTOKOL KESEHATAN DI LINGKUNGAN KAMPUS POLTEKKES KEMENKES MAKASSAR
}

Level of Student Compliance in the Application of Health Protocols at the Health Polytechnic of Makassar

Andi Tenriyola Madjid, Andi Ruhban, Rafidah

Jurusan Kesehatan Lingkungan Poltekkes Kemenkes Makassar

*) anditenriyola15@gmail.com

\begin{abstract}
Compliance is a change in attitude from an attitude that does not obey the rules to an attitude that obeys the rules. Community compliance is still a phenomenon that must continue to be improved in the application of health protocols to improve behavior in breaking the chain of transmission from the Covid-19 virus. The type of research used is the type of observational research with a descriptive approach. The instrument in this study was an online questionnaire using a google form, then processed using Microsoft Excel. The population is all students of Poltekkes Kemenkes Makassar with a sample of 365 people distributed in 8 majors. The results showed that student compliance in the application of health protocols by washing hands with soap was $75,61 \%$, the highest was majoring in dental health $87,50 \%$ and the lowest was majoring in physiotherapy $53,65 \%$. Compliance with wearing masks is $87,12 \%$, the highest is environmental health majors $95,12 \%$ and the lowest is Makassar nursing majors 68,29\%. Meanwhile, adherence to social distancing was $67,13 \%$, the highest is obstetrics major $75,60 \%$ and the lowest is pharmacy majors $58,53 \%$. From the results of the study, it can be conclude that students are obedient in the application of health protocols at the Health Polytechnic Of Makassar. It is hoped that students can participate in efforts to properly handle the spread of Covid-19 cases. However, monitoring is needed from the campus and the government in order to maintain a conducive situation in an effort to break the chain of transmission of COVID-19.
\end{abstract}

Keywords: Compliance, Health Protocol, Students

\section{ABSTRAK}

Kepatuhan adalah perubahan sikap dari sikap yang tidak mentaati aturan ke sikap yang mentaati aturan. Kepatuhan masyarakat masih menjadi fenomena yang harus terus ditingkatkan dalam penerapan protokol kesehatan untuk memperbaiki perilaku dalam memutus mata rantai penularan dari virus Covid-19. Jenis penelitian yang digunakan adalah jenis penelitian observasi dengan pendekatan deskriptif. Instrumen dalam penelitian ini kuesioner online dengan menggunakan google form, kemudian diolah menggunakan microsoft excel. Populasi adalah seluruh mahasiswa Poltekkes Kemenkes Makassar dengan sampel sebanyak 365 orang yang terdistribusi di 8 jurusan. Hasil penelitian didapatkan bahwa kepatuhan mahasiswa dalam penerapan protokol kesehatan dengan mencuci tangan pakai sabun $75,61 \%$, tertinggi jurusan kesehatan gigi $87,50 \%$ dan terendah jurusan fisioterapi $53,65 \%$. Kepatuhan memakai masker $87,12 \%$, tertinggi jurusan kesehatan lingkungan $95,12 \%$ dan terendah jurusan keperawatan makassar $68,29 \%$. Sedangkan kepatuhan menjaga jarak 67,13\%, tertinggi jurusan kebidanan 75,60\% dan terendah jurusan farmasi $58,53 \%$. Dari hasil penelitian dapat disimpulkan bahwa mahasiswa patuh dalam penerapan protokol kesehatan di kampus Poltekkes Kemenkes Makassar. Hal ini diharapkan mahasiswa dapat ikut dalam upaya penanganan penyebaran kasus Covid-19 dengan baik. Namun demikian, diperlukan pemantauan dari pihak kampus dan pemerintah agar tetap mempertahankan situasi yang kondusif dalam upaya pemutusan mata rantai penularan covid-19.

Kata Kunci: Kepatuhan, Protokol Kesehatan, Mahasiswa

\section{PENDAHULUAN}

Masalah kesehatan yang sedang dihadapi dunia saat ini akibat virus baru yang mengguncang dunia adalah wabah penyakit coronavirus (Covid-19). COVID-19 adalah penyakit yang disebabkan oleh coronavirus baru yang disebut SARSCoV2. WHO adalah yang pertama mengetahui tentang virus baru ini. Menyusul serangkaian kasus "virus pneumonia" yang dilaporkan di Wuhan, Republik Rakyat Tiongkok pada 31 Desember 2019. (World Health Organitation, 2020b)

Coronavirus Disease 2019 (Covid-19) adalah penyakit menular yang disebabkan oleh Severe Acute Respiratory Syndrome Coronavirus 2 (SARS-CoV-2). SARSCoV2 adalah virus baru yang belum pernah diidentifikasi pada manusia. Setidaknya ada dua virus corona yang diketahui dapat menyebabkan gejala parah seperti Middle East Respiratory Syndrome (MERS) dan Severe Acute Respiratory Syndrome (SARS). (Kemenkes RI, 2020)

Kasus Covid-19 sampai saat ini masih terus bertambah. Data global yang dilaporkan berdasarkan catatan WHO tanggal 12 Januari 2021 mencapai angka 89.707.116 kasus terkonfirmasi dengan angka kematian mencapai 1.940.352. Angka kasus tertinggi ditempati oleh negara Amerika dengan jumlah kasus sebanyak 39,552,693 dengan angka kematian sebesar 921.256, lalu diikuti oleh India sebanyak 10.479 .179 dengan angka kematian sebesar 151.327, dan Brasil de4ngan jumlah kasus sebesar 8.105.790 dengan jumlah kematian 203.100. Sedangkan di Indonesia sendiri saa ini kejadian Covid-19 
Jurnal Sulolipu : Media Komunikasi Sivitas Akademika dan Masyarakat

Vol. 21 No.2 2021

e-issn : 2622-6960, p-issn : 0854-624X

terkonfirmasi sebesar 836.718 kasus dengan angka kematian sebesar 24.434. (World Health Organitation, 2021)

Di Provinsi Sulawesi Selatan, kasus Covid-19 juga terus mengalami peningkatan setiap harinya. Dari data yang didapat tanggal 12 Januari 2021, jumlah kasus di Provinsi Sulawesi Selatan terkonfirmasi 37.766 kasus dengan angka kematian sebesar 652 jiwa. Dan khusus untuk kota Makassar sendiri jumlah kasus terkonfirmasi 19.275 kasus dengan angka kematian sebanyak 407 jiwa. (Sulsel Tanggap Covid-19, 2021)

Pemerintah Indonesia telah menyatakan keadaan darurat terkait dengan mewabahnya virus ini. Cara terbaik untuk mengendalikan dan mencegah penyakit ini adalah dengan memutus mata rantai Covid-19. Berdasar pada penelitian yang dilakukan Martias et al., 2020 bahwa terdapat 60\% masyarakat tidak patuh terhadap himbauan pemerintah terkait protokol kesehatan. Oleh karena itu, upaya pemutusan mata rantai penularan dapat dilakukan dengan menerapkan protokol kesehatan secara disiplin. Yakni sering mencuci tangan dengan sabun dan air mengalir atau hand sanitizer, memakai masker, menghindari menyentuh wajah sebelum mencuci tangan, dan menjaga jarak selama beraktivitas yang dikenal sebagai 3M. (Kemenkes RI, 2020)

Penelitian yang didapatkan Anggreni dan Safitri terhadap sampel 111 orang menunjukkan bahwa tidak menemukan hubungan antara pengetahuan remaja tentang Covid-19 dengan kepatuhan terhadap protokol kesehatan. Meski pemerintah telah mengeluarkan kebijakan dan himbauan terkait protokol kesehatan masih banyak masyarakat yang melanggar. Banyak faktor yang mempengaruhi derajat ketidakpatuhan seseorang, salah satunya motivasi atau dukungan dari anggota keluarga dan dirinya sendiri. Keluarga diharapkan dapat memberikan contoh dan motivasi untuk mau menerapkan protokol kesehatan dimanapun mereka berada. (Anggreni \& Safitri, 2020).

Selain itu, ditemukan bahwa terdapat lima faktor yang terkait dengan kepatuhan terhadap protokol kesehatan yaitu usia, pendidikan, pengetahuan, sikap, dan motivasi (Afrianti \& Rahmiati, 2021). Hal ini juga sejalan dengan adanya penelitian dimana pengetahuan dan perilaku atau sikap masyarakat cukup baik terkait protokol kesehatan seperti memakai masker, kebiasaan cuci tangan dan physical/sosial distancing. (Purnamasari \& Raharyani, 2020)
Kepatuhan masyarakat masih menjadi fenomena yang harus terus ditingkatkan untuk memperbaiki perilaku dalam memutus mata rantai penularan dari virus Covid-19. Sehingga berdasarkan uraian dan penjelasan tersebut maka penulis tertarik melakukan penelitian mengenai "Tingkat Kepatuhan Mahasiswa dalam Protokol Kesehatan di Kampus Poltekkes Kemenkes Makassar".

\section{METODE}

\section{Desain, tempat dan waktu}

Jenis penelitian yang digunakan adalah jenis penelitian observasi dengan pendekatan deskriptif menggunakan skala likert. Adapun variabel bebas dalam penenlitian ini adalah protokol kesehatan (mencuci tangan pakai sabun, memakai masker dan menjaga jarak) dan variabel terikat adalah kepatuhan mahasiswa.

Populasi dalam penenlitian ini adalah seluruh mahasiswa Poltekkes Kemenkes Makassar. pengambilan sampel dilakukan dengan metode simple random sampling dengan jumlah sampel sebanyak 365 responden. Adapun kriteria inklusi dan ekslusi pada penelitian ini, yaitu:

1. Kriteria inklusi

a. Mahasiswa terdaftar aktif sebagai civitas akademika Poltekkes Kemenkes Makassar.

b. Sedang dan atau pernah berada dalam lingkungan kampus Poltekkes Kemenkes Makassar

c. Sedang dan atau pernah mengikuti pembelajaran luring selama PPKM berlangsung (praktik laboratorium, workshop)

d. Bersedia menjadi responden

2. Kriteria eklusi

a. Tidak pernah mengikuti pembelajaran luring di lingkungan kampus Poltekkes Kemenkes Makassar

b. tidak memiliki HP android dan akses internet

Penelitian ini dilakukan di kampus Poltekkes Kemenkes Makassar yang dilaksanakan pada tanggal 10 Mei - 4 Juni 2021.

\section{Jenis dan Cara Pengumpulan Data}

\section{Teknik Pengumpulan Data}

Data primer adalah data yang diperoleh langsung oleh peneliti, melalui survei berbentuk google form yang disebarkan melalui WhatApp, dan data lain 
yang dapat digunakan sebagai sumber data primer untuk penelitian ini.

Data sekunder diperoleh dari berbagai referensi baik dari buku, jurnal dan media internet maupun literatur yang lain dianggap dapat mendukung teori yang ada serta dianggap memiliki keterkaitan dengan penelitian ini.

\section{Prosedur Pengumpulan Data}

Dalam penelitian ini teknik pengumpulan data yang digunakan adalah kuesioner. Kuesioner adalah lembar penilaian yang diberikan kepada responden (mahasiswa) untuk menilai kepatuhan mahasiswa dalam penerapan protokol kesehatan di kampus Poltekkes Kemenkes Makassar.

\section{Instrumen Pengumpulan Data}

Instrumen penelitian adalah alat yang digunakan untuk mengukur variabel yang diamati. Dalam pengumpulan data penelitian ini dilakukan secara online menggunakan kuesioner dengan bantuan google form dimana link tersebut disebarkan melalui via WhatsApp ke sejumlah mahasiswa untuk kemudian diisi.

\section{Pengolahan dan analisis data}

Pengolahan data dilakukan dengan menggunakan komputer dibantu dengan alat hitung dengan skala Likert. Data yang diperoleh dari hasil kuesioner disajikan dalam bentuk tabel.

Analisis data dilakukan setelah pengumpulan dan pengolahan data, setelah itu data diolah secara deskriptif berdasarkan persentase (\%).

\section{HASIL}

Berdasarkan pada tabel 1dilihat bahwa jenis kelamin mahasiswa di Poltekkes Kemenkes Makassar yang diperoleh dari 365 responden yang paling terbanyak yaitu jenis kelamin perempuan sebanyak 327 responden $(89,59 \%)$. Sedangkan yang paling rendah yaitu jenis kelamin laki-laki sebanyak 38 responden $(10,41 \%)$. umur responden mahasiswa di Poltekkes Kemenkes Makassar yang diperoleh dari 365 responden yang paling terbanyak yaitu berumur 20 tahun sebanyak 115 responden $(31,50 \%)$. Sedangkan yang paling rendah yaitu berumur 35 tahun hanya 1 responden $(0,27 \%)$. Pada program studi mahasiswa di Poltekkes Kemenkes Makassar yang diperoleh dari 365 responden, yang terbanyak yaitu program studi DIII sebanyak
237 responden (64,93\%). Sedangkan yang paling rendah yaitu program studi profesi sebanyak 6 responden $(1,64 \%)$. Sedangkan pada tingkatan semester mahasiswa di Poltekkes Kemenkes Makassar yang diperoleh dari 365 responden, yang paling tertinggi yaitu semester 6 sebanyak 128 responden $(35,06 \%)$. Sedangkan yang paling rendah yaitu semester 8 sebanyak 37 responden (10,14\%).

Dari tabel 2 dapat dilihat bahwa pada jurusan mahasiswa di Poltekkes Kemenkes Makassar yang diperoleh dari 365 responden, terdapat 6 jurusan dengan responden terbanyak yaitu jurusan kesehatan lingkungan, keperawatan makassar, kebidanan, farmasi, fisioterapi dan gizi sebanyak 41 responden $(11,23 \%)$. Sedangkan yang paling rendah yaitu jurusan teknik laboratorium media/analis kesehatan sebanyak 39 responden $(10,70 \%)$. Tingkat kepatuhan tertinggi dalam mencuci tangan pakai sabun mahasiswa jurusan kesehatan gigi $(87,50 \%)$ dan terendah jurusan fisioterapi (53,65\%). Kepatuhan tertinggi dalam memakai masker mahasiswa jurusan kesehatan lingkungan (95,12\%) dan terendah jurusan Keperawatan Makassar (68,29\%). Sedangkan kepatuhan tertinggi dalam menjaga jarak mahasiswa jurusan kebidanan $(75,60 \%)$ dan terendah jurusan farmasi $(58,53 \%)$.

Pada tabel 3 kepatuhan mahasiswa terhadap protokol kesehatan mencuci tangan pakai sabun di kampus Poltekkes Kemenkes Makassar, yaitu sebagian besar mahasiswa patuh melakukan cuci tangan pakai sabun sebanyak 276 responden $(75,62 \%)$ dan sebagian mahasiswa tidak patuh melakukan cuci tangan pakai sabun sebanyak 86 responden $(24,38 \%)$.

Pada tabel 4 hasil tingkat kepatuhan mahasiswa terhadap protokol kesehatan memakai masker di kampus Poltekkes Kemenkes Makassar sebagian besar mahasiswa patuh memakai masker sebanyak 318 responden (87,12\%). Meski demikian masih terdapat sebagian kecil mahasiswa yang tidak patuh memakai masker sebanyak 47 responden (12,88\%).

Dan pada tabel 5 dilihat bahwa hasil tingkat kepatuhan mahasiswa terhadap protokol kesehatan menjaga jarak di kampus Poltekkes Kemenkes Makassar sebagian besar mahasiswa patuh menjaga jarak sebanyak 245 responden $(67,13 \%)$ dan sebagian mahasiswa tidak patuh menjaga jarak sebanyak 120 responden (32,87\%). 


\section{PEMBAHASAN}

1. Penerapan Protokol Kesehatan Mencuci Tangan Pakai Sabun di Kampus Poltekkes Kemenkes Makassar

Berdasarkan hasil penelitian penerapan protokol kesehatan di kampus Poltekkes Kemenkes Makassar mencuci tangan pakai sabun dan air mengalir terhadap 365 responden diketahui bahwa terdapat 276 responden (75,62\%) mahasiswa patuh terhadap protokol kesehatan cuci tangan pakai sabun dan mahasiswa yang tidak patuh sebanyak 86 responden (24,38\%). Diketahui bahwa tingginya tingkat kepatuhan mahasiswa dalam penerapan protokol kesehatan mencuci tangan pakai sabun dan air mengalir di kampus Poltekkes Kemenkes Makassar dapat mengurangi penyebaran covid-19 sehingga akan menekan angka bertambahnya kasus baru. Hal ini didukung dengan adanya sarana cuci tangan di lingkungan kampus. Penelitian ini sejalan dengan penelitian Afrianti \& Rahmiati, (2021), menunjukkan bahwa 89,6\% masyarakat memiliki kepatuhan yang tinggi terhadap protokol kesehatan.

Hasil peneltian didapatkan tingkat kepatuhan tertinggi penerapan protokol kesehatan dalam mencuci tangan pakai sabun di kampus Poltekkes Kemenkes Makassar ada pada jurusan kesehatan gigi $(87,50 \%)$. Tingginya kepatuhan mencuci tangan pakai sabun di jurusan kesehatan gigi menunjukkan bahwa mahasiswa di jurusan kesehatan gigi menerapkan protokol kesehatan dengan baik. Namun, kepatuhan mencuci tangan pakai sabun di jurusan fisioterapi $(53,65 \%)$ cukup rendah di banding dengan jurusan lain. Berdasarkan data tersebut menunjukkan bahwa sangat perlunya sosialisasi mengenai protokol kesehatan mulai dari mencuci tangan dengan benar melalui berbagai platform sosial media dan penyediaan fasilitas cuci tangan di lingkungan kampus.

Salah satu cara yang efektif yang dapat membunuh kuman dan bakteri dengan mencuci tangan karena tangan adalah medium krusial dalam transmisi virus-virus yang ditularkan melalui air, darah atau produk darah, makan, sistem pencernaan, percikan pernapasan, serta sentuhan baik langsung maupun tidak langsung. Menggosok tangan menggunakan sabun dan air bersih yang mengalir dapat menghilangkan kontaminan kotoran dan mikroba pada kulit.

Berdasar pada penelitian Ataee et al., (2017), perilaku mencuci tangan pakai sabun dan air bersih yang mengalir sangat dianjurkan karena merupakan salah satu cara efektif untuk mencegah transmisi penularan infeksi virus dan bakteri, virus covid-19 diketahui dapat menempel pada bagian tubuh terutama tangan yang bersentuhan dengan benda yang terkontaminasi droplet. Maka upaya yang paling sederhana untuk menegakkan pilar hidup sehat dan mencegah menempelnya virus pada tangan adalah dengan gemar cuci tangan. Kementerian kesehatan mengatakan bahwa penularan covid-19 melalui percikan air ludah pada benda sebanyak $75 \%$.

Selain menggunakan sabun dan air, etanol $61-70 \%$ juga dapat digunakan untuk mengurangi infektivitas virus. Oleh sebab itu, handsanitizer berbasis alkohol merupakan alternatif lain dalam mencuci tangan. Hal ini dikarenakan alkohol lebih disukai saat tangan terlihat bersih sedangkan sabun dan air bersih yang mengalir digunakan saat tangan terlihat lebih kotor.

\section{Penerapan Protokol Kesehatan Memakai Masker di Kampus Poltekkes Kemenkes Makassar \\ Berdasarkan hasil penelitian} kepatuhaan penggunaan masker dalam penerapan protokol kesehatan di kampus Poltekkes Kemenkes Makassar didapatkan hasil bahwa dari 365 responden diketahui bahwa terdapat 318 responden $(87,12 \%)$ mahasiswa patuh dalam menerapkan selalu memakai masker di lingkungan kampus dan mahasiswa yang tidak patuh sebanyak 47 responden (12,88\%). Tingginya tingkat kepatuhan mahasiswa dalam menerapkan protokol kesehatan memakai masker menunjukkan bahwa mahasiswa menyadari akan pentingnya menggunakan masker bahaya penyebaran virus yang kian melunjak serta adanya instruksi pemakaian masker saat berada di lingkungan Poltekkes Kemenkes Makassar.

$\mathrm{Hal}$ tersebut sejalan dengan penelitian yang dilakukan oleh Purnamasari \& Raharyani (2020) dimana 72,2\% masyarakat telah mematuhi penggunaan masker sebagai upaya pencegahan penyebaran covid-19. Hal ini dikarenakan pemakaian masker bertujuan untuk 
menahan 'pembawa' penularan virus dan memblokir virus itu sendiri. Adapun cara yang biasanya digunakan untuk penularan virus melalui pernapasan meliputi kontak dekat dalam jarak pendek dan transmisi aerosol dan droplet jarak jauh. Aerosol ini berupa bersin yang dapat ditularkan. Salah satu cara yang efektif dalam menahan/memblokir bersin dan mencegah virus masuk ke dalam tubuh secara langsung dengan mengenakan/menggunakan masker secara baik dan benar.

Hasil penelitian didapatkan penerapan protokol kesehatan memakai masker di kampus Poltekkes Kemenkes Makassar tertinggi pada jurusan kesehatan lingkungan dengan persentase $95,12 \%$. Hal ini didukung dengan penelitian Martias et al., 2020 dimana mahasiswa patuh menggunakan masker yaitu $88,89 \%$ dalam melakukan upaya pencegahan covid-19. Hal ini dikarenakan banyaknya media promosi kesehatan yang fokus memberikan pengetahuan bagi masyarakat terkait pencegahan dan pengobatan covid- 19 . Namun, rendahnya penggunaan masker di jurusan Keperawatan Makassar dengan persentase $68,29 \%$ dapat menyebabkan penyebaran covid-19. Salah satu faktor yang mempengaruhi tingkat kepatuhan mahasiswa dalam memakai masker adalah tingkat pengetahuan, tingkat pengetahuan yang tinggi ini juga didukung dengan tingkat pendidikan sebagian besar responden berpendidikan tinggi (diploma dan sarjana).

Sejalan dengan penelitian Purnamasari \& Raharyani, 2020 dimana $99 \%$ masyarakat indonesia mempunyai pengetahuan yang baik. Tingginya tingkat pendidikan seseorang maka akan semakin mudah untuk mendapatkan informasi terkait permasalah kesehatan di dunia. Oleh karena itu, mahasiswa harus pintar menggunakan media informasi yang dapat memotivasi dalam memakai masker guna memutus rantai penularan covid-19.

Masker bedah merupakan masker yang mempunyai efektifitas yang baik terhadap pencegahan karena memiliki tingkat perlindungan $56 \%$ dari partikel dengan ukuran nanometer, namun sebagai upaya pencegahan penularan covid-19 melalui percikan air ludah/droplet masyarakat masih dapat menggunakan masker kain. Oleh karena itu, sebagai mahasiswa kesehatan wajib menerapkan protokol kesehatan memakai masker di lingkungan kampus maupun diluar kampus guna memberikan contoh kepada masyarakat awam atas pentingnya penggunaan masker agar terhindar dari percikan air/droplet sebagai upaya pencegahan penularan covid-19.

\section{Penerapan Protokol Kesehatan Menjaga Jarak di Kampus Poltekkes Kemenkes Makassar}

Penelitian ini juga memperlihatkan mahasiswa selalu menerapkan protokol kesehatan menjaga jarak diketahui bahwa sebanyak 245 responden (67,13\%) mahasiswa cenderung lebih patuh terhadap protokol kesehatan menjaga jarak dan mahasiswa yang tidak patuh sebanyak 120 responden (32,87\%). Tingginya kepatuhan mahasiswa dalam mengatur jarak antar mahasiswa lain dan menghindari keramaian yang memungkinkan terjadinya penumpukan orang dapat memperkecil risiko tertular penyakit.

Hasil penelitian didapatkan kepatuhan tertinggi dalam penerapan protokol kesehatan di kampus Poltekkes Kemenkes Makassar ada pada jurusan kebidanan dengan persentase $75,60 \%$. Hal ini dikarenakan pihak jurusan menekankan agar penerapan jaga jarak aman dan disiplin melaksanakan protokol kesehatan dengan baik. Sedangkan terendah jurusan farmasi dengan persentase $58,65 \%$. Frekuensi ini cukup mengkhawatirkan mengingat semakin kurangnya disiplin protokol kesehatan maka akan semakin meningkatkan risiko terpapar Covid-19 ini. Hal ini dikarenakan terdapat beberapa faktor yang mempengaruhi rendahnya tingkat kepatuhan protokol kesehatan menjaga jarak di jurusan farmasi, salah satunya yaitu kurangnya perhatian dari pihak jurusan terkait protokol kesehatan menjaga jarak sehingga tidak terdapat batasan (tanda silang) pada setiap kursi di ruang tunggu.

Tingginya kepatuhan mahasiswa dikarenakan adanya kebijakan pemerintah dan instansi untuk menerapkan e-learning atau belajar dari rumah, sehingga mahasiswa, dosen, dan tenaga kependidikan tidak saling berinteraksi satu sama lain secara langsung, namun dapat berinteraksi melalui media sosial, google meet, ataupun aplikasi meeting lainnya. Elearning atau belajar dari rumah ini mengikuti pedoman pemerintah dan 
mewajibkan mahasiswa untuk melakukan social distancing dan isolasi mandiri selama masa pandemi Covid-19. Kegiatan perkuliahan kali ini dilakukan secara virtual untuk pencegahan penyebaran Covid-19.

E-learning atau perkuliahan secara daring dilakukan untuk memastikan mahasiswa berada pada jarak yang baik dan dapat melanjutkan aktivitas belajarnya. Poltekkes Kemenkes Makassar menerapkan kebijakan belajar dan bekerja dari rumah, dan menerapkan sistem selektif bagi pendidik dan tenaga kependidikan perorangan untuk tetap bekerja di kantor dalam menjalankan tugasnya.

Mahasiswa melakukan langkahlangkah positif untuk mencegah penyebaran covid19, seperti menghindari kegiatan yang memobilisasi massa dalam jumlah besar di wilayah yang tidak terlalu luas dan padat penduduk. Hal ini dianggap sebagai salah satu upaya yang paling efektif dalam pencegahan penyebaran covid-19.

Hasil penelitian ini sejalan dengan penelitian Widyaningrum et al (2020) menjelaskan bahwa kepatuhan dalam melakukan protokol kesehatan menjaga jarak dalam taraf baik yang ditunjukkan dengan responden melakukan kegiatan di luar ruangan hanya jika ada keperluan yang mendesak.

Dari ketiga aspek penerapan protokol kesehatan dilihat bahwa ketidakpatuhan dalam penerapan protokol kesehatan didominasi oleh jurusan fisioterapi. Meskipun terdapat aturan penerapan protokol kesehatan 3M (mencuci tangan pakai sabun dan air, memakai masker dan menjaga jarak) wajib saat memasuki area kampus jurusan fisioterapi, masih ada saja mahasiswa yang melanggar atau tidak patuh. Hal ini dikarenakan kurang tegasnya penegakan peraturan protokol kesehatan di jurusan fisioterapi. Selain itu, ketidakpatuhan ini dipengaruhi oleh beberapa faktor. Salah satu faktor ketidakpatuhan terhadap suatu permasalahan yaitu motivasi. Kurangnya motivasi dari orang sekitar dapat mengakibatkan mahasiswa cenderung berperilaku tidak baik terutama dalam menjaga kesehatan dan keselamatan diri. Oleh karena itu, pihak kampus Poltekkes Kemenkes Makassar jurusan fisioterapi diperlukan penegasan dan aturan yang ketat dalam penerapan protokol kesehatan terutama apabila terdapat mahasiswa yang tidak menerapkan protokol kesehatan dengan baik seusai dengan kebijakan yang telah ditetapkan.

Kepatuhan mahasiswa dalam mematuhi protokol kesehatan sangat dianjurkan dalam masa pandemi covid-19. $\mathrm{Hal}$ ini didukung oleh Afrianti dan Rahmiati (2021) dimana terdapat 89,9\% masyarakat memiliki kepatuhan yang tinggi terhadap protokol kesehatan covid-19. Sama halnya dengan hasil survei yang dilakukan Badan Pusat Statistik (BPS) pada tahun 2020. Studi tersebut menyebutkan bahwa masyarakat Indonesia sudah cukup patuh dalam menerapkan protokol kesehatan untuk memblokir virus Covid-19.

Mayoritas mahasiswa di kampus Poltekkes Kemenkes Makassar telah menerapkan protokol kesehatan dengan baik. Penerapan protokol kesehatan sangat perlu diterapkan, baik dalam kehidupan sehari-hari, lingkungan kampus, maupun lingkungan rumah tangga. Adapun bentuk pengimplementasiannya dalam kampus Poltekkes Kemenkes Makassar telah menerapkan kebijakan perkuliahan secara daring, social distancing, menyediakan sarana cuci tangan di lingkungan kampus, melakukan sosialisasi dan membuat poster yang berisi edukasi terkait pencegahan Covid-19. Hal ini sesuai dengan salah satu argumen Kissler et al. (2020) bahwa implementasi protokol kesehatan sangat penting untuk mengendalikan penyebaran Covid-19.

Penerapan protokol kesehatan di kampus Poltekkes Kemenkes Makassar sangat diperlukan dalam memutuskan penyebaran covid-19 ini. Oleh karena itu, mahasiswa sebagai agen of change yang seharusnya ikut dalam upaya mencegah penyebaran covid-19 khususnya dalam lingkup kampus Poltekkes Kemenkes Makassar.

Pemerintah telah mengeluarkan kebijakan baru terkait protokol kesehatan. Kebijakan protokol kesehatan yang berlaku untuk saat ini yaitu protokol kesehatan $5 \mathrm{M}$ (Mencuci tangan, Memakai masker, Menjaga jarak, Menjauhi kerumunan dan Mengurangi mobilitas). Penambahan protokol kesehatan ini guna mencegah terjadinya penularan Covid- 19 .

\section{KESIMPULAN}

Berdasarkan hasil penelitian dan pembahasan tentang tingkat kepatuhan mahasiswa dalam penerapan protokol 
Jurnal Sulolipu : Media Komunikasi Sivitas Akademika dan Masyarakat

Vol. 21 No.2 2021

e-issn : 2622-6960, p-issn : 0854-624X

kesehatan di kampus Poltekkes Kemenkes Makassar, maka dapat disimpulkan bahwa:

1. Kepatuhan mahasiswa dalam menerapkan protokol kesehatan mencuci tangan pakai sabun di kampus Poltekkes Kemenkes Makassar berada pada kategori patuh yaitu sebanyak 75,62\%, dengan tingkat kepatuhan tertinggi pada jurusan kesehatan gigi sebanyak $87,50 \%$ dan terendah jurusan fisioterapi sebanyak $53,65 \%$.

2. Kepatuhan mahasiswa dalam menerapkan protokol kesehatan memakai masker di kampus Poltekkes Kemenkes Makassar berada pada kategori patuh yaitu sebanyak $87,12 \%$ dengan tingkat kepatuhan tertinggi pada jurusan kesehatan lingkungan sebanyak $95,12 \%$ dan terendah jurusan keperawatan makassar sebanyak 68,29\%.

3. Kepatuhan mahasiswa dalam menerapkan protokol kesehatan menjaga jarak di kampus Poltekkes Kemenkes Makassar berada pada kategori patuh yaitu sebanyak $67,13 \%$ dengan tingkat kepatuhan tertinggi pada jurusan kebidanan sebanyak $75,60 \%$ dan terendah jurusan farmasi $58,53 \%$.

\section{SARAN}

1. Kepatuhan terhadap protokol kesehatan dipengaruhi oleh banyak faktor. Oleh karena itu, mahasiswa harus mendapatkan informasi dan pengetahuan yang akurat tentang Covid19 serta dukungan dan motivasi untuk lebih mematuhi protokol kesehatan.

2. Kepada pihak Kampus Poltekkes Kemenkes Makassar masih perlu dilakukan upaya untuk mencegah penyebaran COVID-19 dengan menjaga jarak sosial melalui berbagai cara seperti mencuci tangan dengan sabun dan air mengalir, memakai masker, menjaga jarak, dll. Untuk itu diperlukan upaya sosialisasi dan edukasi, memasang poster pengendalian infeksi COVID-19 dan promosi kesehatan terutama terhadap mahasiswa.

3. Penelitian ini dapat dijadikan acuan bagi peneliti selanjutnya terkait pencegahan penyebaran covid-19. Diharapkan peneliti selanjutnya dapat menggunakan metode yang berbeda seperti jumlah sampe dan dilengkapi literatur yang lebih banyak.

\section{DAFTAR PUSTAKA}

Afrianti, N., \& Rahmiati, C. (2021). Faktor-faktor yang mempengaruhi kepatuhan masyarakat terhadap protokol kesehatan covid-19. Jurnal IImiah SRIKES Kendal, 001, 113-124. http://journal.stikeskendal.ac.id/index.php/PSKM/article/view/1045/647 diakses tanggal 4 Januari 2021

Anggreni, D., \& Safitri, C. A. (2020). Hubungan Pengetahuan Remaja Tentang Covid-19 Dengan Kepatuhan Dalam Menerapkan Protokol Kesehatan Di Masa New Normal. 12(2), 134-142. http://ejournal.stikesmajapahit.ac.id/index.php/HM/article/view/662/669 diakses tanggal 25 Desember 2020

Ataee, R. A., Ataee, M. H., Tavana, A. M., \& Salesi, M. (2017). Bacteriological Aspects of Hand Washing: A Key for Health Promotion and Infections Control. International Jurnal of Preventive Medicine, 8(16). https://doi.org/10.4103/2008-7802.201923 diakses pada tanggal 7 Januari 2021

Kemenkes RI. (2020). Pedoman Pencegahan dan Pengendalian Coronavirus Disease (Covid19). Pedoman Covid Rev 4, 1(Revisi ke-4), 1-125. http://jurnalrespirologi.org/index.php/jri/article/view/101 diakses tanggal 2 Januari 2021

Kissler, S., Tedijanto, C., Lipsitch, M., \& Grad, Y. H. (2020). Social Distancing Strategies for Curbing The COVID-19 Epidemic. Harvard Edu, 49(1), 40-44. https://doi.org/10.11392/jsao.49.40 diakses tanggal 1 Mei 2021

Martias, I., Pitriyanti, L., \& Aldo, N. (2020). Studi Tingkat Kepatuhan Masyarakat Provinsi Kepulauan Riau Untuk Melaksanakan Social/Physical Distancing Dalam Upaya Mencegah Penyebaran Virus Covid-19. Jurnal Sulolipu: Media Komunikasi Sicitas Akademika Dan Masyarakat., 20(2). journal.poltekkes-mks.ac.id. diakses tanggal 10 Desember 2021

Purnamasari, I., \& Raharyani, A. E. (2020). Tingkat Pengetahuan Dan Perilaku Masyarakat Kabupaten Wonoboso Tentang Covid -19. Jurnal IImiah Kesehatan Diagnosis, Mei, 33-42. https://ojs.unsiq.ac.id/index.php/jik/artic le/view/1311/783. diakses tanggal 22 November 2020

Widyaningrum, N., Putri, Y. D., \& Wilopo. (2020). Gambaran Penerapan Physical Distancing Sebagai Upaya Menekan Persebaran Covid-19 di Provinsi Daerah Istimewa Yogyakarta. 
Jurnal Sulolipu : Media Komunikasi Sivitas Akademika dan Masyarakat

Vol. 21 No.2 2021

e-issn : 2622-6960, p-issn : 0854-624X

Jurnal IImu Pengetahuan Sosial, 7(2), 470-481. http://jurnal.umtapsel.ac.id/index.php/nusantara/article/view/1766 diakses tanggal 19 Januari 2021

World Health Organitation. (2020a). Anjuran Mengenai Penggunaan Masker dalam Konteks Covid-19. April. https://www.who.int/docs/default-source/searo/indonesia/covid19/anjuranmengenai-penggunaan-masker-dalam-konteks-covid-19.pdf?sfvrsn=8a209b04_2 diakses tanggal 23 Desember 2020

World Health Organitation. (2020b). Coronavirus disease (COVID-19). https://www.who.int/emergencies/diseases/novel-coronavirus-2019/question-and-answershub/q-a-detail/coronavirus-disease-covid-19 diakses tanggal 12 Januari 2021 
Jurnal Sulolipu : Media Komunikasi Sivitas Akademika dan Masyarakat Vol. 21 No.2 2021

e-issn : 2622-6960, p-issn : 0854-624X

Tabel 1

Distribusi Frekuensi Karakteristik Subjek Tingkat Kepatuhan Mahasiswa di Lingkungan Kampus Poltekkes Kemenkes Makassar

\begin{tabular}{|c|c|c|}
\hline \multirow{2}{*}{ Karakteristik } & \multicolumn{2}{|c|}{ Subjek } \\
\hline & $\mathbf{N}$ & $\%$ \\
\hline \multicolumn{3}{|l|}{ Jenis Kelamin } \\
\hline Laki-laki & 38 & 10,41 \\
\hline Perempuan & 327 & 89,59 \\
\hline \multicolumn{3}{|l|}{ Lama Masa Pendidikan } \\
\hline Semester 2 & 81 & 22,2 \\
\hline Semester 4 & 119 & 32,6 \\
\hline Semester 6 & 128 & 35,06 \\
\hline Semester 8 & 37 & 10,14 \\
\hline \multicolumn{3}{|l|}{ Jurusan } \\
\hline Keperawatan Makassar & 41 & 11,23 \\
\hline Kebidanan & 40 & 11.23 \\
\hline Gizi & 41 & 11,23 \\
\hline Kesehatan Lingkungan & 41 & 11,23 \\
\hline Kesehatan Gigi & 40 & 10,96 \\
\hline Analis Kesehatan & 39 & 10,70 \\
\hline Keperawatan Parepare & 40 & 10,96 \\
\hline Fisioterapi & 41 & 11,23 \\
\hline Farmasi & 41 & 11,23 \\
\hline \multicolumn{3}{|l|}{ Jenis Pendidikan vokasi } \\
\hline DIII & 237 & 64,93 \\
\hline Sarjana Terapan & 122 & 33,43 \\
\hline Profesi & 6 & 1,64 \\
\hline
\end{tabular}

Sumber: Data Primer 2021

Tabel 2 
Jurnal Sulolipu : Media Komunikasi Sivitas Akademika dan Masyarakat

Vol. 21 No.2 2021

e-issn : 2622-6960, p-issn : 0854-624X

Distribusi Tingkat Kepatuhan Mahasiswa Berdasarkan Jurusan di Lingkungan Kampus Poltekkes Kemenkes Makassar

\begin{tabular}{|c|c|c|c|c|c|c|c|c|}
\hline \multirow{2}{*}{ No } & \multirow{2}{*}{ Jurusan } & \multicolumn{2}{|c|}{$\begin{array}{c}\text { Cuci Tangan Pakai } \\
\text { Sabun }\end{array}$} & \multicolumn{2}{|c|}{ Memakai Masker } & \multicolumn{2}{|c|}{ Menjaga Jarak } & \multirow{2}{*}{$\begin{array}{l}\text { Jumlah } \\
\text { Mahasiswa }\end{array}$} \\
\hline & & Patuh & $\begin{array}{l}\text { Tdk } \\
\text { Patuh }\end{array}$ & Patuh & $\begin{array}{l}\text { Tdk } \\
\text { Patuh }\end{array}$ & Patuh & $\begin{array}{c}\text { Tdk } \\
\text { Patuh }\end{array}$ & \\
\hline 1 & $\begin{array}{l}\text { Teknik } \\
\text { Laboratorium } \\
\text { Medis }\end{array}$ & $\begin{array}{c}32 \\
(82,05 \%)\end{array}$ & $\begin{array}{c}7 \\
(17,95 \%)\end{array}$ & $\begin{array}{c}33 \\
(84,61 \%)\end{array}$ & $\begin{array}{c}6 \\
(15,39 \%)\end{array}$ & $\begin{array}{c}30 \\
(76,92 \%)\end{array}$ & $\begin{array}{c}9 \\
(23,08 \%)\end{array}$ & $\begin{array}{c}39 \\
(10,70 \%)\end{array}$ \\
\hline 2 & Kesling & $\begin{array}{c}29 \\
(70,73 \%)\end{array}$ & $\begin{array}{c}12 \\
(29,27 \%)\end{array}$ & $\begin{array}{c}39 \\
(95,12 \%)\end{array}$ & $2(4,88 \%)$ & $\begin{array}{c}26 \\
(63,41 \%)\end{array}$ & $\begin{array}{c}15 \\
(36,59 \%)\end{array}$ & $\begin{array}{c}41 \\
(11,23 \%)\end{array}$ \\
\hline 3 & Kep Makassar & $\begin{array}{c}33 \\
(80,48 \%)\end{array}$ & $\begin{array}{c}8 \\
(19,52 \%)\end{array}$ & $\begin{array}{c}28 \\
(68,29 \%)\end{array}$ & $\begin{array}{c}13 \\
(31,71 \%)\end{array}$ & $\begin{array}{c}28 \\
(68,29 \%)\end{array}$ & $\begin{array}{c}13 \\
(31,71 \%)\end{array}$ & $\begin{array}{c}41 \\
(11,23 \%)\end{array}$ \\
\hline 4 & Kep Parepare & $\begin{array}{c}31 \\
(77,5 \%)\end{array}$ & $9(22,5 \%)$ & $30(75 \%)$ & $10(25 \%)$ & $30(75 \%)$ & $10(25 \%)$ & $\begin{array}{c}40 \\
(10,96 \%)\end{array}$ \\
\hline 5 & Kep Gigi & $\begin{array}{c}35 \\
(87,50 \%)\end{array}$ & $\begin{array}{c}5 \\
(12,50 \%)\end{array}$ & $\begin{array}{c}36 \\
(90,00 \%)\end{array}$ & $\begin{array}{c}4 \\
(10,00 \%)\end{array}$ & $\begin{array}{c}30 \\
(75,00 \%)\end{array}$ & $\begin{array}{c}10 \\
(25,00 \%)\end{array}$ & $\begin{array}{c}40 \\
(10,96 \%)\end{array}$ \\
\hline 6 & Kebidanan & $\begin{array}{c}34 \\
(82,92 \%)\end{array}$ & $\begin{array}{c}7 \\
(17,07 \%)\end{array}$ & $\begin{array}{c}36 \\
(87,80 \%)\end{array}$ & $\begin{array}{c}5 \\
(12,20 \%)\end{array}$ & $\begin{array}{c}31 \\
(75,60 \%)\end{array}$ & $\begin{array}{c}10 \\
(24,40 \%)\end{array}$ & $\begin{array}{c}41 \\
(11,23 \%)\end{array}$ \\
\hline 7 & Farmasi & $\begin{array}{c}29 \\
(70,73 \%)\end{array}$ & $\begin{array}{c}12 \\
(29,27 \%)\end{array}$ & $\begin{array}{c}36 \\
(87,80 \%)\end{array}$ & $\begin{array}{c}5 \\
(12,20 \%)\end{array}$ & $\begin{array}{c}21 \\
(58,53 \%)\end{array}$ & $\begin{array}{c}20 \\
(41,47 \%)\end{array}$ & $\begin{array}{c}41 \\
(11,23 \%)\end{array}$ \\
\hline 8 & Fisioterapi & $\begin{array}{c}22 \\
(53,65 \%)\end{array}$ & $\begin{array}{c}19 \\
(46,35 \%)\end{array}$ & $\begin{array}{c}32 \\
(78,04 \%)\end{array}$ & $\begin{array}{c}9 \\
(21,96 \%)\end{array}$ & $\begin{array}{c}23 \\
(56,09 \%)\end{array}$ & $\begin{array}{c}18 \\
(43,91 \%)\end{array}$ & $\begin{array}{c}41 \\
(11,23 \%)\end{array}$ \\
\hline 9 & Gizi & $\begin{array}{c}31 \\
(75,60 \%)\end{array}$ & $\begin{array}{c}10 \\
(24,40 \%)\end{array}$ & $\begin{array}{c}38 \\
(92,68 \%)\end{array}$ & $3(7,32 \%)$ & $\begin{array}{c}25 \\
(60,97 \%)\end{array}$ & $\begin{array}{c}15 \\
(39,03 \%)\end{array}$ & $\begin{array}{c}41 \\
(11,23 \%)\end{array}$ \\
\hline \multicolumn{8}{|c|}{ Total } & 365 \\
\hline
\end{tabular}

Sumber: Data Primer 2021

Tabel 3

Distribusi Tingkat Kepatuhan Mahasiswa dalam Protokol Kesehatan Mencuci Tangan Pakai Sabun di Lingkungan Kampus Poltekkes Kemenkes Makassar

\begin{tabular}{cccc}
\hline No & Tingkat Kepatuhan & Frekuensi & Persentase (\%) \\
\hline 1 & Patuh & 276 & 75,62 \\
2 & Tidak Patuh & 89 & 24,38 \\
& Total & 365 & 100 \\
\hline
\end{tabular}

Sumber: Data Primer 2021 
Jurnal Sulolipu : Media Komunikasi Sivitas Akademika dan Masyarakat Vol. 21 No.2 2021

e-issn : 2622-6960, p-issn : 0854-624X

Tabel 4

Distribusi Tingkat Kepatuhan Mahasiswa dalam Protokol Kesehatan Memakai Masker di Lingkungan Kampus Poltekkes Kemenkes Makassar

\begin{tabular}{cccc}
\hline No & Tingkat Kepatuhan & Frekuensi & Persentase (\%) \\
\hline 1 & Patuh & 318 & 87,12 \\
2 & Tidak Patuh & 47 & 12,88 \\
& Total & 365 & 100 \\
\hline
\end{tabular}

Sumber: Data Primer 2021

Tabel 5

Distribusi Tingkat Kepatuhan Mahasiswa dalam Protokol Kesehatan Menjaga Jarak di Lingkungan Kampus Poltekkes Kemenkes Makassar

\begin{tabular}{cccc}
\hline No & Tingkat Kepatuhan & Frekuensi & Persentase (\%) \\
\hline 1 & Patuh & 245 & 67,13 \\
2 & Tidak Patuh & 120 & 32,87 \\
& Total & 365 & 100 \\
\hline
\end{tabular}

Sumber: Data Primer 2021 